\title{
Photocatalytic decolorization of crystal violet in aqueous nano-ZnO suspension under visible light irradiation
}

\author{
Md Ahsan Habib*, Muhammad Muslim', Md Tusan Shahadat', Md Nazrul Islam², Iqbal Mohmmad Ibrahim Ismail ${ }^{3}$, \\ Tajmeri Selima Akhter Islam ${ }^{1}$ and Abu Jafar Mahmood ${ }^{1 *}$
}

\begin{abstract}
Nanosized $\mathrm{ZnO}$ was prepared through hydrothermal process and characterized by scanning electron microscopy, $\mathrm{X}$-ray diffraction and laser-induced breakdown spectra measurement techniques. The as-prepared nanosized ZnO was used to investigate the decolorization/degradation of crystal violet, a cationic dye which is extensively used in dyeing/textile industries, under visible light through adsorption studies of the dye solution with $\mathrm{ZnO}$ in the dark. The results show that the adsorption of $\mathrm{CV}$ on $\mathrm{ZnO}$ takes about 200 min to reach equilibrium, and the equilibrium time at a certain concentration of the dye seems to be independent of temperatures that are used for the preparation of $\mathrm{ZnO}$ samples. The adsorption data follow the pseudo-first-order kinetic model (Lagergren), and the adsorption pattern follows the Langmuir model.

Prepared $\mathrm{ZnO}\left(300^{\circ} \mathrm{C}\right)$ was found to be a more efficient photocatalyst among others including pristine $\mathrm{ZnO}$, to decolorize/degrade the dye. The decolorization rate is increased with the decreasing of the initial dye concentration and reached at a limiting value. The catalyst loading also influences the decolorization/degradation of the dye, and decolorization rate is increased with increasing the catalyst loading and reached at a limiting value. $\mathrm{ZnO}$ was found to be stable under visible light irradiation at solution $\mathrm{pH}=6$. The photocatalytic degradation of the dye followed zero-order kinetics, and the Langmuir-Hinshelwood mechanism was found to be valid.
\end{abstract}

Keywords: Nanosize ZnO; Photocatalyst; Lagergren model; Decolorization/degradation; Langmuir-Hinshelwood model

\section{Background}

Crystal violet $(\mathrm{CV})$ is a triarylmethane dye which is extensively used in industries such as textile/dyeing, ballpoint pen, paper, leather, additives, foodstuffs, cosmetics, and analytical chemistry [1,2]. CV is also used in biological staining. CV binds to DNA, so it has been used in cell viability assays in biochemistry. However, this binding to DNA will cause replication errors in living tissue, possibly leading to mutations and cancer. Toxicological investigations indicate that crystal violet has carcinogenic and mutagenic effects in rodents [3]. It has also been linked to increased risk of human bladder cancer. Therefore, it is treated as a serious pollutant in

\footnotetext{
*Correspondence: habibchemdu@yahoo.com; ajmahmood10@gmail.com 'Department of Chemistry, Faculty of Science, University of Dhaka, Dhaka 1000, Bangladesh

Full list of author information is available at the end of the article
}

wastewater and difficult to treat by common removal methods such as coagulation and biodegradation, but few studies on its treatment have been attempted [1,4]. The release of wastewater containing the dye poses a dramatic source of water pollution, eutrophication, and perturbation of aquatic life. Therefore, a method is highly required of treating wastewater containing CV.

In the last few decades, much attention has been paid to investigate degradation of organic pollutants mediated by $\mathrm{TiO}_{2}$ particles in aqueous suspension under UV-light irradiation [5-12]. Recent studies indicate that $\mathrm{ZnO}$ can also be used as a promising photocatalyst to degrade such types of organic pollutants under visible/solar irradiation [13-16]. However, artificial UV light and $\mathrm{TiO}_{2}$ particles tend to be somewhat expensive, and the UV component in sunlight reaching the earth surface and 
available to excite $\mathrm{TiO}_{2}$ is relatively small (ca. $3 \%$ to $5 \%$ ), whereas solar spectrum has about $40 \%$ visible region.

Organic pollutants like dyestuffs have the ability to absorb visible light. The electron transfer process from dye to semiconductor, especially $\mathrm{ZnO}$ has been found to be very effective. Initially, the dye molecules adsorb on $\mathrm{ZnO}$ surface and excited through absorption light. The excited dye ( $\left.D^{*}\right)$ injects an electron to the conduction band of $\mathrm{ZnO}$ where it is scavenged by $\mathrm{O}_{2}$ to form active oxygen radicals. The consequence of electron ejection into the conduction band results hole-electron pair formation. These hole-electron pairs are responsible of generating other reactive oxygen species like $\mathrm{OH}, \mathrm{HO}_{2}$, $\mathrm{H}_{2} \mathrm{O}_{2}$, and also $\mathrm{O}_{2}^{-}$. These active radicals are responsible for photodegradation or mineralization of organic compounds. The mechanism can be attributed as follows:

$$
\begin{aligned}
& D_{\text {ads }}+h v_{\text {vis }} \rightarrow{ }^{*} D_{\text {ads }} \\
& { }^{*} D_{\text {ads }}+\mathrm{ZnO} \rightarrow \mathrm{ZnO}(e)+D^{+} \text {ads } \\
& \mathrm{ZnO}(e)+\mathrm{O}_{2} \rightarrow \mathrm{O}_{2}{ }^{-}+\mathrm{ZnO} \\
& { }^{*} \mathrm{D}_{\text {ads }}+\mathrm{ZnO} \rightarrow \mathrm{D}_{\text {ads }}+h^{+}+e^{-} \\
& h^{+}+\mathrm{H}_{2} \mathrm{O} \rightarrow \mathrm{OH}+\mathrm{H}^{+} \\
& \mathrm{O}_{2}{ }^{-}+\mathrm{H}^{+} \rightarrow \mathrm{HO}_{2} \\
& 2 \mathrm{HO}_{2} \rightarrow \mathrm{H}_{2} \mathrm{O}_{2}+\mathrm{O}_{2} \\
& \mathrm{H}_{2} \mathrm{O}_{2}+\mathrm{O}_{2}{ }^{-} \rightarrow \mathrm{OH}+\mathrm{OH}^{-}+\mathrm{O}_{2} \\
& \mathrm{H}_{2} \mathrm{O}_{2}+e^{-} \rightarrow \mathrm{OH}+\mathrm{OH}^{-}
\end{aligned}
$$

Dye + reactive oxygen species $($ ROS $) \rightarrow$ Degradated /mineralized products.

Recently, we reported [13] a comparative study of decolorization of Ponceau S (PS), an anionic dye, in pristine $\mathrm{ZnO}$ and prepared $\mathrm{ZnO}$ suspensions. The $\mathrm{ZnO}$ was prepared through the hydrothermal method. We found that the prepared $\mathrm{ZnO}\left(300^{\circ} \mathrm{C}\right)$ showed better efficiency to decolorize/degrade Ponceau S. In this report, $\mathrm{CV}$, a cationic dye, has been taken as an example of wastewater pollutants in different industries. Photocatalytic degradation of $\mathrm{CV}$ has been reported recently in the presence of $\mathrm{TiO}_{2}$ [1,8-11] under UV irradiation. So far, no attempt has been taken to use $\mathrm{ZnO}$ instead of $\mathrm{TiO}_{2}$ as a photocatalyst to decolorize/degrade CV. However, $\mathrm{ZnO}$ takes part in photocorrosion under UV radiation at lower solution $\mathrm{pH}$ (approximately 6.0). Therefore, the present study focuses on decolorization/degradation of $\mathrm{CV}$ in aqueous suspension of $\mathrm{ZnO}$ under visible light irradiation with a variety of conditions. In addition, an adsorption study of $\mathrm{CV}$ on $\mathrm{ZnO}$ is also discussed.

\section{Results and discussion}

\section{Adsorption of $\mathrm{CV}$ from solution on $\mathrm{ZnO}$}

Adsorption studies of CV solution $\left(2.50 \times 10^{-5} \mathrm{M}\right)$ with $\mathrm{ZnO}(0.20 \mathrm{~g} / 40.0 \mathrm{~mL})$ in dark are shown in Figure 1. The results show that the adsorption of $\mathrm{CV}$ on $\mathrm{ZnO}$ takes about 200 min to reach equilibrium. The equilibrium time at a certain concentration seems to be independent of temperatures that are used for the preparation of $\mathrm{ZnO}$ samples. The adsorption data have also been fitted to pseudo-first-order (Lagergren) and the pseudo-second-order kinetic equations of the adsorption processes (data not shown). The values of correlation coefficients $\left(r^{2}\right)$ for the pseudo-first-order kinetic model are between 0.994 to 0.998 and those for the pseudo-second-order kinetic model between 0.963 to 0.989 . These results seem to suggest that adsorption of $\mathrm{CV}$ from solution on $\mathrm{ZnO}$ favors the pseudo-first-order adsorption model. Results further suggest that the commercial $\mathrm{ZnO}$ has been made at a temperature higher than $300^{\circ} \mathrm{C}$.

The shapes of adsorption isotherms $\left(30^{\circ} \mathrm{C}\right)$ indicate that adsorption of $\mathrm{CV}$ from solution on $\mathrm{ZnO}$ will reach plateau at its certain concentration as shown in Figure 2. In the range of $\mathrm{CV}$ concentration up to $2.50 \times 10^{-5} \mathrm{M}$, $C_{\mathrm{e}} /(x / m)_{\mathrm{e}}$ vs $C_{\mathrm{e}}$ plots are linear (data not shown) which suggests the Langmuir model, and the corresponding correlation coefficient are satisfactory $\left(r^{2}=0.992\right.$ to 0.998). However, plots of $\ln (x / m)_{\mathrm{e}}$ vs $\ln C_{\mathrm{e}}$ (data not shown) suggest the Freundlich model and show straight lines, but $r^{2}$ values vary between 0.967 and $0.984, r^{2}=$ 0.967 for $\mathrm{ZnO}$ prepared at $300^{\circ} \mathrm{C}$. Therefore, it is suggested that the adsorption pattern of $\mathrm{CV}$ on $\mathrm{ZnO}$ favors the Langmuir model that also was observed for Ponceau $\mathrm{S}$, an anionic dye, on $\mathrm{ZnO}$ [13].

The kinetic data $(k)$ and Langmuir parameters $\left(Q_{\mathrm{m}}\right.$ and $K_{\mathrm{L}}$ ) (Table 1) are likely to suggest that increasing the heating temperatures during the preparation of $\mathrm{ZnO}$ samples to higher values causes agglomeration of $\mathrm{ZnO}$ particles, decreasing thereby the active adsorption sites. Accordingly, adsorption of $\mathrm{CV}$ on $\mathrm{ZnO}$ falls as the temperature of heating is raised during the preparation of $\mathrm{ZnO}$ samples. The amount of $\mathrm{CV}$ adsorbed $(25 \%$ $\left([\mathrm{CV}]=2.50 \times 10^{-5} \mathrm{M}, \mathrm{Temp} .=30^{\circ} \mathrm{C}, \mathrm{pH}=6, \mathrm{ZnO}=\right.$ $0.20 \mathrm{~g} / 40.0 \mathrm{~mL}), Q_{\mathrm{m}}=0.31 \mathrm{mg} / \mathrm{g}$ ) at a particular time 


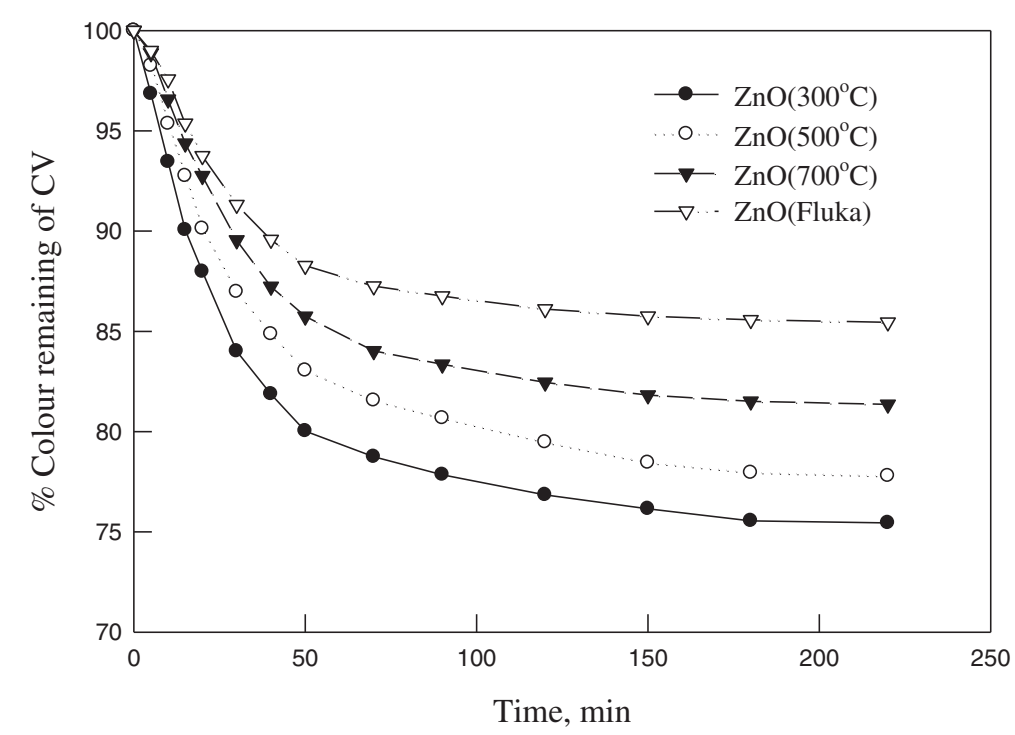

Figure 1 Absorption of CV from solution by $\mathrm{ZnO}$. $[\mathrm{CV}]=2.50 \times 10^{-5} \mathrm{M}, \mathrm{ZnO}=0.20 \mathrm{~g} / 40.0 \mathrm{~mL}, \mathrm{pH}=6$, Temp. $=30^{\circ} \mathrm{C}$.

and concentration is the highest in the case of $\mathrm{ZnO}$ prepared at $300^{\circ} \mathrm{C}$.

Adsorption of a dye on a semiconducting metal oxide surface, as on the surface of $\mathrm{ZnO}$, is a prerequisite for the successful photodecolorization of the dye. Consequently, the adsorption studies were necessary.

The better adsorption characteristics of the $\mathrm{CV}$ from solution on $\mathrm{ZnO}$ made at $300^{\circ} \mathrm{C}$, were the criteria for selecting this $\mathrm{ZnO}$ sample for studying the visible lightinfluenced degradation. The higher value of $K_{\mathrm{L}-\mathrm{H}}$ compared to $K_{\mathrm{L}}$ (Table 1) suggests that there is some surface activation by the visible light used in this study. This activation should be considerably low to promote valence band electrons to the conduction band as the band gap energy for $\mathrm{ZnO}$ is $3.2 \mathrm{eV}\left(\lambda_{\max } \approx 388 \mathrm{~nm}\right)$.

\section{ZnO-mediated photodecolorization CV}

The initial $\mathrm{pH}$, in the range 3.75 to 6.02 , of $\mathrm{CV}$ solutions did not affect on its UV-vis spectra. The spectrum of the $\mathrm{CV}$ solution before illumination with visible light (Figure 3) has characteristic prominent peaks at 590, 302 , and $250 \mathrm{~nm}$ corresponding to conjugated triphenyl

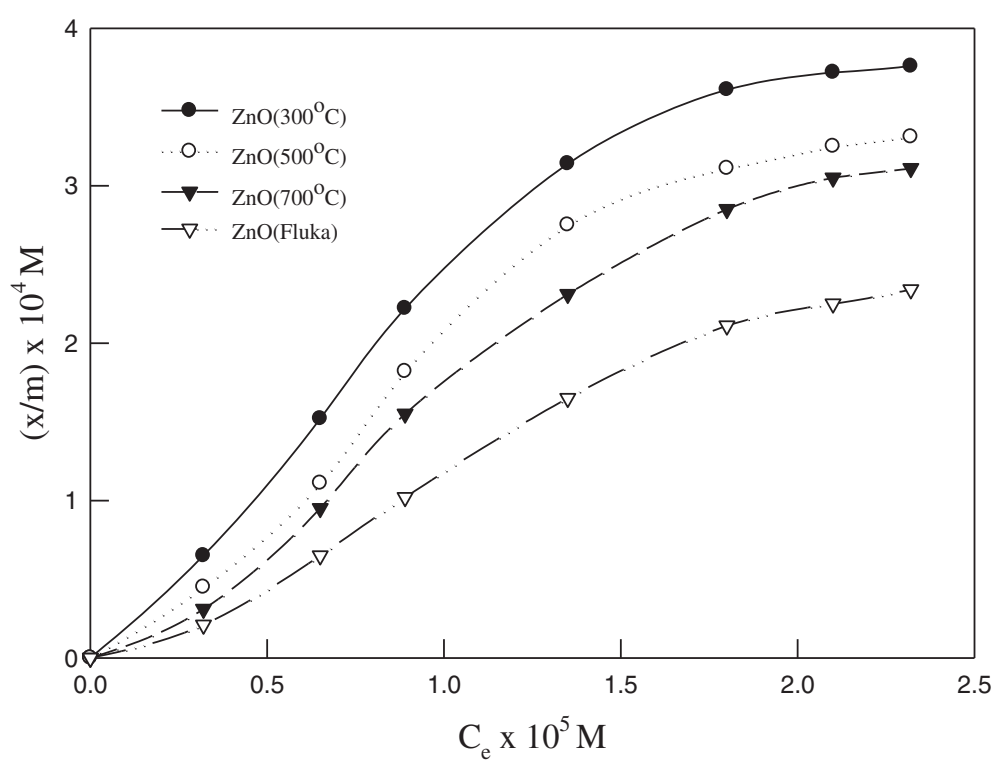

Figure 2 Adsorption isotherms of CV. $\mathrm{ZnO}=0.20 \mathrm{~g} / 40.0 \mathrm{~mL}, \mathrm{pH}=6$, Temp. $=30^{\circ} \mathrm{C}$. 
Table 1 The kinetic and equilibrium parameters for adsorption of CV from solution on $\mathrm{ZnO}$

\begin{tabular}{|c|c|c|c|c|c|}
\hline \multirow[t]{3}{*}{$\mathrm{ZnO}$} & \multicolumn{2}{|c|}{ Rate constant } & \multirow[t]{3}{*}{$R_{\mathrm{L}}$} & \multicolumn{2}{|c|}{ Equilibrium constant } \\
\hline & $k_{1} \times 10^{2} I$ & $k_{2} \times 10^{3}$ & & $K_{\mathrm{L}} \times 10^{-3}$ & $Q_{m}$ \\
\hline & & $\mathrm{g} / \mathrm{mg} / \mathrm{min}$ & & $\mathrm{L} / \mathrm{mol}$ & $\mathrm{mg} / \mathrm{g}$ \\
\hline \multirow[t]{2}{*}{$300^{\circ} \mathrm{C}$} & 4.13 & 9.72 & & 4.16 & 0.31 \\
\hline & $r^{2}=0.999$ & $r^{2}=0.981$ & & $r^{2}=0.999$ & \\
\hline \multirow[t]{2}{*}{$500^{\circ} \mathrm{C}$} & 3.73 & 5.07 & & 4.00 & 0.26 \\
\hline & $r^{2}=0.998$ & $r^{2}=0.980$ & 0.91 & $r^{2}=0.990$ & \\
\hline \multirow[t]{2}{*}{$700^{\circ} \mathrm{C}$} & 3.35 & 2.15 & & 3.92 & 0.21 \\
\hline & $r^{2}=0.994$ & $r^{2}=0.978$ & & $r^{2}=0.989$ & \\
\hline \multirow[t]{2}{*}{ Commercial } & 2.77 & 0.98 & & 3.83 & 0.16 \\
\hline & $r^{2}=0.995$ & $r^{2}=0.988$ & & $r^{2}=0.985$ & \\
\hline
\end{tabular}

Temp. $=30^{\circ} \mathrm{C}, \mathrm{pH}=6.02$.

methane chromophore, diphenyl methyl type, $\phi_{2} \mathrm{C}=(\phi$, $\mathrm{C}_{6} \mathrm{H}_{5}$ ), and benzene moieties, respectively. The decrease in absorbance at $590 \mathrm{~nm}$ with illumination is due to the breakdown of the chromophore responsible for the characteristic color of $\mathrm{CV}$. This breakdown, caused by the visible light illumination of $\mathrm{CV}$ in the aqueous suspension of $\mathrm{ZnO}$ particles, leads to the formation of intermediates like benzophenone and benzene derivatives [17]. Some of the benzene derivatives are benzoic acid and aniline derivatives. All of these compounds are finally mineralized to $\mathrm{CO}_{2}, \mathrm{H}_{2} \mathrm{O}$, and $\mathrm{NO}_{3}^{-}$. The hypsochromic shift of the peak at $590 \mathrm{~nm}$ of the chromophore to about $575 \mathrm{~nm}$ is of particular significance as it indicates $\mathrm{N}$-dimethylation process [18] that ultimately generates $\mathrm{NO}_{3}^{-}$ions $[19,20]$.

Figure 3 shows that the characteristic peaks gradually disappear with the time of illumination. When the illumination was continued for about $360 \mathrm{~min}([\mathrm{CV}]=2.00 \times$
$10^{-5} \mathrm{M}$ ), none of the peaks could be detected. The residual spectrum with a peak near about $200 \mathrm{~nm}$ disappears when very dilute solution of $\mathrm{NaNO}_{3}$ is used as reference in the place of water. This suggested the presence of $\mathrm{NO}_{3}^{-}$ ions, as one of the products formed during visible light degradation of $\mathrm{CV}$ in the $\mathrm{ZnO}$ suspension.

Figure 4 shows how decolorization and disappearance of total organic carbon (TOC) progress with time of illumination of $\mathrm{CV}$ in $\mathrm{ZnO}$ suspension. The decrease of $\mathrm{TOC}$ with time of illumination is the actual mineralization of $\mathrm{CV}$, that is, the conversion of $\mathrm{CV}$ molecules to $\mathrm{CO}_{2}, \mathrm{H}_{2} \mathrm{O}$, $\mathrm{N}_{2}$, and $\mathrm{NO}_{3}^{-}$ions. TOC measures $\mathrm{CO}_{2}$ formed from the carbon atoms of $\mathrm{CV}$ molecules. Accordingly, TOC measures complete degradation of $\mathrm{CV}$ molecules. With $\mathrm{ZnO}=0.20 \mathrm{~g} / 40 \mathrm{~mL}$ and $[\mathrm{CV}]=2.00 \times 10^{-5} \mathrm{M}$, it needs about $360 \mathrm{~min}$ for complete mineralization of $\mathrm{CV}$ molecules in the suspension. On the other hand, for complete decolorization, it takes about $200 \mathrm{~min}$; therefore, it is concluded that decolorization is faster than degradation.

\section{Influence of $\mathrm{ZnO}$ on decolorization of $\mathrm{CV}$}

The initial rate of decolorization of $\mathrm{CV}$ also increases with the increasing of the concentration of $\mathrm{ZnO}$ in the suspension (data not shown). However, this increase seems to be linear up to about $0.15 \mathrm{~g} \mathrm{ZnO} / 40 \mathrm{~mL}$. Subsequently, deceleration of the initial rate of decolorization of CV starts. In our previous studies, it has also been reported that the initial rate of decolorization of an anionic dye, Ponceau $\mathrm{S}$, increases with increasing of $\mathrm{ZnO}$ in suspension [13].

Figure 5 shows that after $5 \mathrm{~min}$, about $28 \%$ decolorization takes place with $0.20 \mathrm{~g} \mathrm{ZnO}$. This decolorization is about $35 \%$ after $5 \mathrm{~min}$ when $0.40 \mathrm{~g} \mathrm{ZnO}$ is used. Moreover, with $0.20 \mathrm{~g} \mathrm{ZnO}$, decolorization increases to

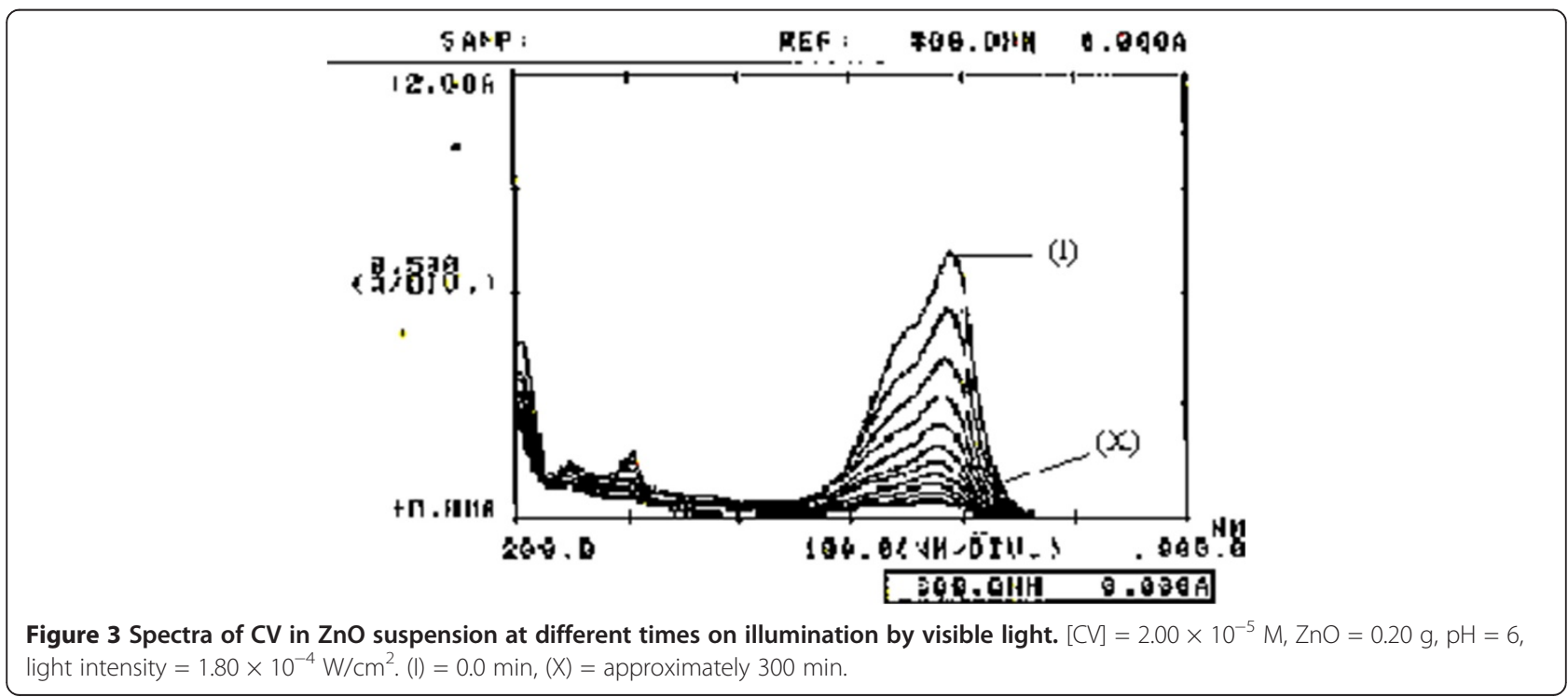




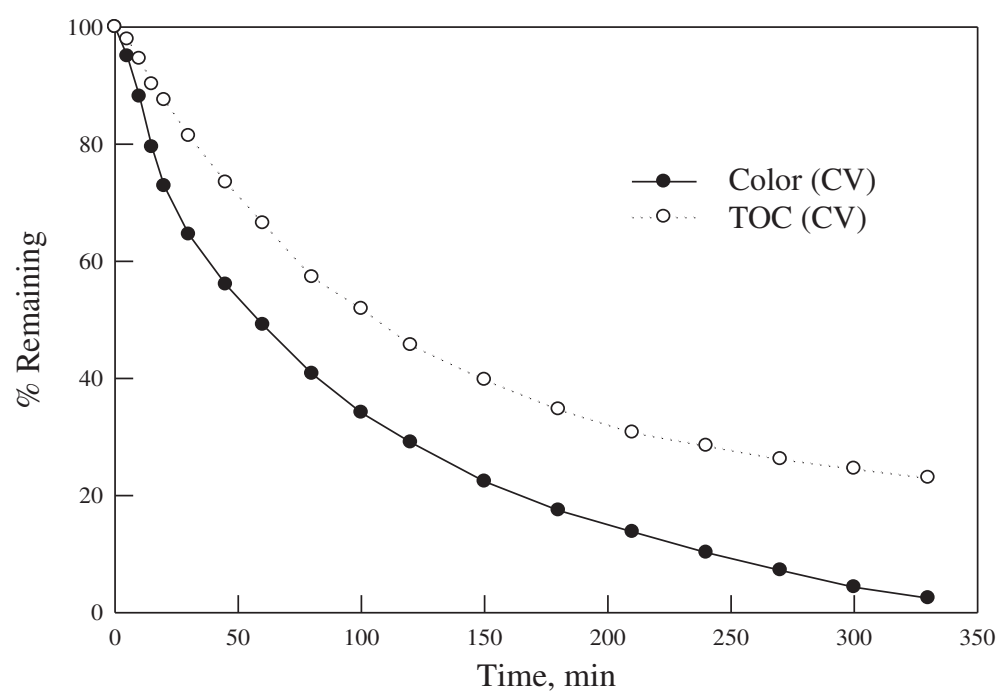

Figure 4 Disappearance of color and TOC of CV in ZnO suspension with time of illumination. [CV] $=2.00 \times 10^{-5} \mathrm{M}, \mathrm{ZnO}=0.20 \mathrm{~g} / 40 \mathrm{~mL}, \mathrm{pH}=6$.

about $43 \%$ after $10 \mathrm{~min}, 51 \%$ after $15 \mathrm{~min}$, and about $62 \%$ after illumination for $30 \mathrm{~min}$. Respectively, under identical times of illumination, with $0.40 \mathrm{~g} \mathrm{ZnO}$, about $46 \%, 55 \%$, and $64 \%$, decolorization takes place. These results suggest that increasing the time of illumination is much useful than increasing the concentration of $\mathrm{ZnO}$ in the suspension. The use of higher concentration, along with longer duration of illumination, does not appear to be that profitable (Table 2). For an example, after $60 \mathrm{~min}$ of illumination, there is about $5 \%$ enhancement of decolorization when $0.40 \mathrm{~g} \mathrm{ZnO} / 40 \mathrm{~mL}$ is used instead of $0.20 \mathrm{~g} \mathrm{ZnO} / 40 \mathrm{~mL}$ (Table 2). The results in Table 2 further show that like PS [13], the increase in turbidity of the suspension, due to increased concentration of $\mathrm{ZnO}$, does not affect the decolorization that much. The reason for this may be ascribed to the continuous stirring of the suspensions in the open air. This replaces $\mathrm{ZnO}$ particles with adsorbed dyes at the surface, exposed to the visible light and having the dye molecules decolorized, by fresh particles with adsorbed dyes from the bulk. The speed

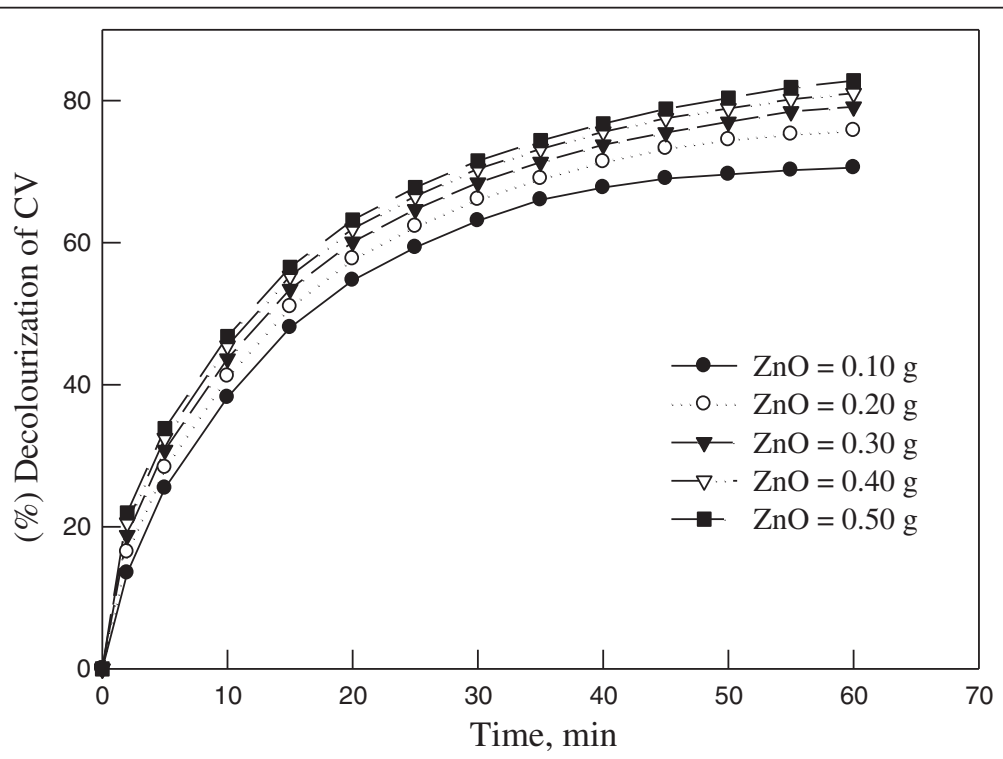

Figure 5 Influence of $\mathrm{ZnO}$ concentration on visible light decolorization of $\mathrm{CV}$ in its suspension. [CV] $=2.00 \times 10^{-5} \mathrm{M}, \mathrm{pH}=6$, suspension $=40 \mathrm{~mL}$. 
Table 2 Influence of various parameters on visible light decolorization of $\mathrm{CV}$ in $\mathrm{ZnO}$ suspensions (Temp $30^{\circ} \mathrm{C}$ )

\begin{tabular}{|c|c|c|c|c|c|c|}
\hline $\begin{array}{l}{[\mathrm{CV}]} \\
\times 10^{5} \mathrm{M}\end{array}$ & $\begin{array}{l}\mathrm{ZnO} \\
\mathrm{g} / 40 \mathrm{~mL}\end{array}$ & $\mathrm{pH}$ & $\begin{array}{l}\text { Initial rate, } R_{\mathrm{i}} \\
\times 10^{6} \mathrm{~mol} / \mathrm{L} / \mathrm{min}\end{array}$ & $\begin{array}{l}\text { Decolorization } \\
\text { after } 60 \mathrm{~min}(\%)\end{array}$ & $\begin{array}{l}K_{\mathrm{L}-\mathrm{H}} \\
\times 10^{-4} \mathrm{~L} / \mathrm{mol}\end{array}$ & $\begin{array}{l}k_{1-\mathrm{H}} \\
\times 10^{6} \mathrm{~mol} / \\
\mathrm{L} / \mathrm{min}\end{array}$ \\
\hline \multirow[t]{5}{*}{2.00} & 0.10 & 6.02 & 0.76 & 70.57 & & \\
\hline & 0.20 & & 1.02 & 75.81 & & \\
\hline & 0.30 & & 1.09 & 79.13 & & \\
\hline & 0.40 & & 1.15 & 81.03 & & \\
\hline & 0.50 & & 1.19 & 82.82 & & \\
\hline 0.50 & 0.20 & 6.02 & 0.41 & 93.83 & & \\
\hline 1.00 & & & 0.69 & 86.79 & & \\
\hline 1.50 & & & 0.88 & 80.82 & 0.77 & 2.37 \\
\hline 2.00 & & & 1.02 & 75.81 & $r^{2}=0.998$ & $r^{2}=0.998$ \\
\hline 2.50 & & & 1.24 & 71.80 & & \\
\hline \multirow[t]{5}{*}{2.00} & 0.20 & 3.75 & 1.02 & 76.30 & & \\
\hline & & 4.22 & 1.03 & 75.21 & & \\
\hline & & 4.88 & 1.03 & 76.52 & & \\
\hline & & 5.35 & 1.02 & 75.39 & & \\
\hline & & 6.02 & 1.02 & 75.81 & & \\
\hline
\end{tabular}

of agitation may have been sufficiently high to help overcome the retarding effect of the higher $\mathrm{ZnO}$ concentration on the movement of the bulk particles to the surface.

Thus, the excess surface sites, provided by the increase in concentration of $\mathrm{ZnO}$, for adsorption of fixed and a small number of CV molecules should have been useful [21]. There had been no loss of these surface sites due to aggregation when $\mathrm{ZnO}$ concentration increases. This loss of surface sites could be one of the dominant factors [20] that are responsible for the deceleration of the initial rate of $\mathrm{CV}$ decolorization with the increase in $\mathrm{ZnO}$ concentration in the suspension.
Various parameters related to $\mathrm{CV}$ decolorization (Table 2) are somewhat lower in comparison to those of PS, an anionic dye [13]. One of the inherent causes is likely to be that $\mathrm{CV}$ has adsorption parameters lower than those of PS.

\section{Influence of concentration of CV}

The trend in the decolorization of $\mathrm{CV}$ solution with its higher concentrations (Figure 6) seems to be similar to that with increasing amounts of $\mathrm{ZnO}$ (Figure 5), and the situation arises because of a small number of adsorption sites on $\mathrm{ZnO}$ in comparison to the increasingly higher

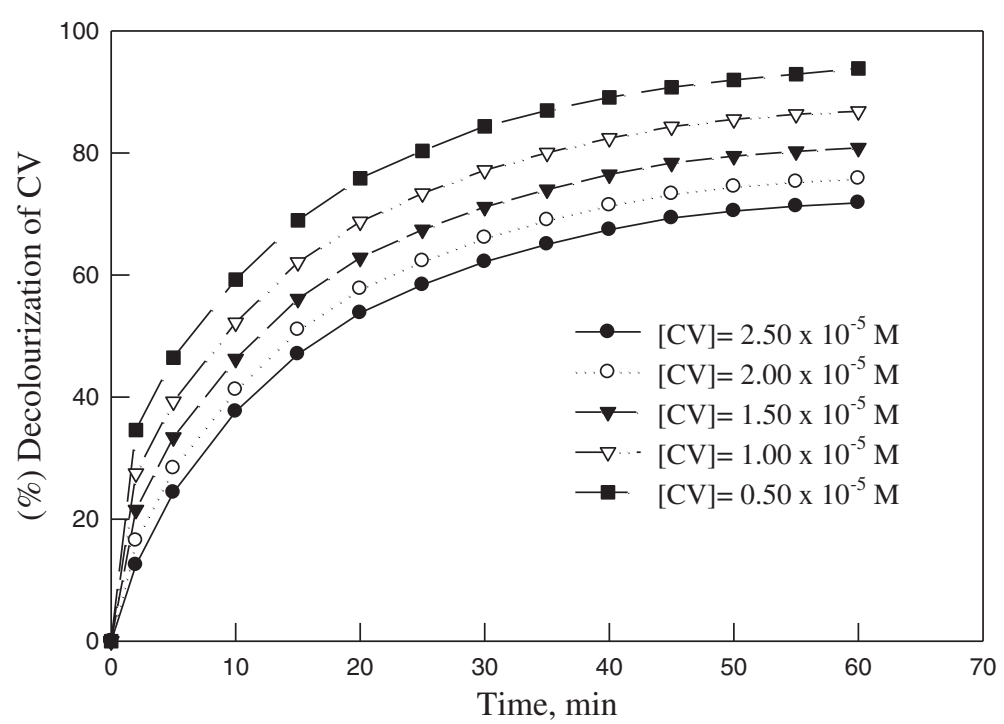

Figure 6 Influence of concentration of CV on its visible light decolorization in $\mathrm{ZnO}$ suspension. $\mathrm{ZnO}=0.20 \mathrm{~g} / 40 \mathrm{~mL}, \mathrm{pH}=6$. 


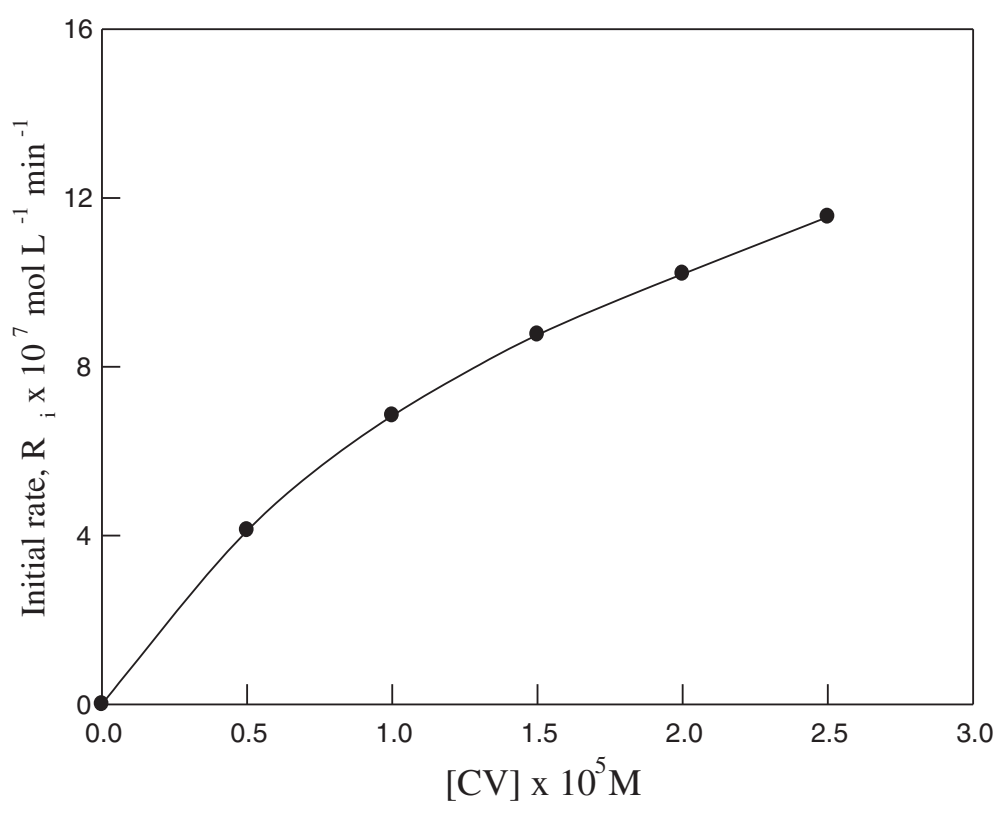

Figure 7 Influence of the concentration of $\mathrm{CV}$ on its initial rate of decolorization in $\mathrm{ZnO}$ suspension. $\mathrm{ZnO}=0.20 \mathrm{~g} / 40 \mathrm{~mL}, \mathrm{pH}=6$.

number of $\mathrm{CV}$ molecules. The initial rate of decolorization of $\mathrm{CV}$ in solution by visible light in the presence of $\mathrm{ZnO}$ seems to remain linear up to the concentration of $\mathrm{CV}$ much less than $1.0 \times 10^{-5} \mathrm{M}$ (Figure 7). As like other dyes, inner filter effect $[13,22,23]$ is also quite prominent in the case of $\mathrm{CV}$ as its concentration in solution increases. The data of variation of initial $\mathrm{CV}$ concentrations, $[\mathrm{CV}]_{\mathrm{i}}$, and initial rates, $R_{\mathrm{i}}$, of disappearance of $\mathrm{CV}$ color from $\mathrm{ZnO}$ suspension, were applied to the Langmuir-Hinshelwood equation in the following form:

$$
\frac{1}{R_{\mathrm{i}}}=\frac{1}{k_{\mathrm{LH}}}+\frac{1}{k_{\mathrm{LH}} K_{\mathrm{LH}}[C V]_{\mathrm{i}}} .
$$

$k_{\mathrm{LH}}$ is a proportionality constant and provides a measure of intrinsic reactivity of $\mathrm{CV}$ adsorbed on $\mathrm{ZnO}$. On the whole, $k_{\mathrm{LH}}$ offers an idea of the apparent rate constant of the reaction involving adsorbed $\mathrm{CV}$ with oxidizing radicals formed at the $\mathrm{ZnO}$ surface. It is the zeroorder surface reaction constant [24]. $K_{\mathrm{LH}}$ is the apparent adsorption equilibrium constant (so called Langmuir-

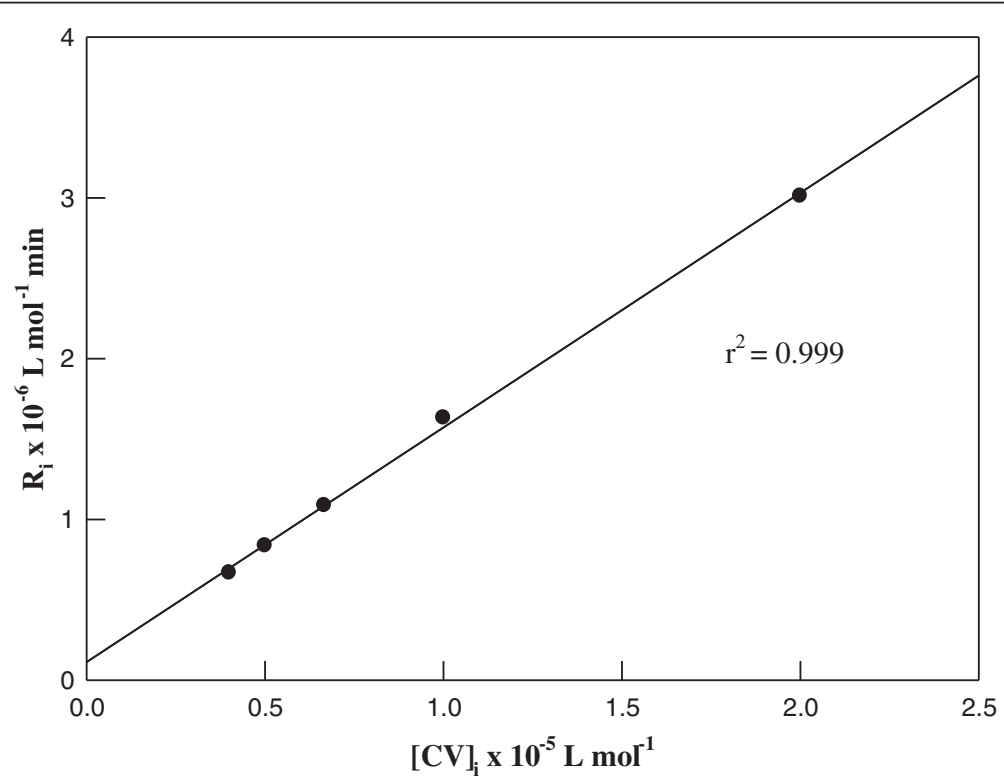

Figure 8 Langmuir-Hinshelwood plot of visible light decolorization of $\mathrm{CV}$ in $\mathrm{ZnO}$ suspension. $\mathrm{ZnO}=0.20 \mathrm{~g} / 40 \mathrm{~mL}, \mathrm{pH}=6, \mathrm{Temp} .=30^{\circ} \mathrm{C}$. 
Hinshelwood constant). $R_{\mathrm{i}}^{-1}$ vs $[\mathrm{CV}]_{\mathrm{i}}^{-1}$ is a nicely fitted straight line (Figure 8 ). $K_{\mathrm{LH}}$ and $k_{\mathrm{LH}}$ values are $7.70 \times$ $10^{3} \mathrm{~L} / \mathrm{mol}$ and $2.37 \times 10^{-6} \mathrm{~mol} / \mathrm{min}$, respectively (Table 1). The higher $K_{\mathrm{LH}}$ value, compared to that of $K_{\mathrm{L}}$ $\left(4.16 \times 10^{3} \mathrm{~L} / \mathrm{mol}\right.$; Table 1$)$, suggests some surface activation of $\mathrm{ZnO}$ surface by visible light.

\section{Conclusions}

Adsorption of $\mathrm{CV}$ on $\mathrm{ZnO}$ aqueous suspension follows the pseudo-first-order kinetic model (Lagergren) while the adsorption pattern follows the Langmuir model; it is a prerequisite condition for semiconductor metal oxidemediated photodegradation. Decolorization results show that $\mathrm{ZnO}$ can efficiently decolorize/degrade $\mathrm{CV}$ in the aqueous suspension under visible light irradiation. $\mathrm{ZnO}$ prepared at $300^{\circ} \mathrm{C}$ shows superior photocatalytic activity compared to the $\mathrm{ZnO}$ samples treated at $500^{\circ} \mathrm{C}$ and $700^{\circ} \mathrm{C}$ and also to the pristine $\mathrm{ZnO}$. The prepared $\mathrm{ZnO}$ has been found to be quite stable under visible light illumination at a $\mathrm{pH}$ of approximately 6 , and there is some activation of the surfaces of $\mathrm{ZnO}$ particles by this light. In addition, remediation of industrial effluents containing some azo dyes by the prepared $\mathrm{ZnO}$ under visible light is underway.

\section{Methods}

\section{Materials}

The dye CV, also known as gentian violet 10B, was obtained from local dye suppliers. The dye shows an absorption maximum at $590 \mathrm{~nm}$. The structure of the dye is shown in Figure 9. Pristine zinc oxide ( $>99.9 \%$ purity,

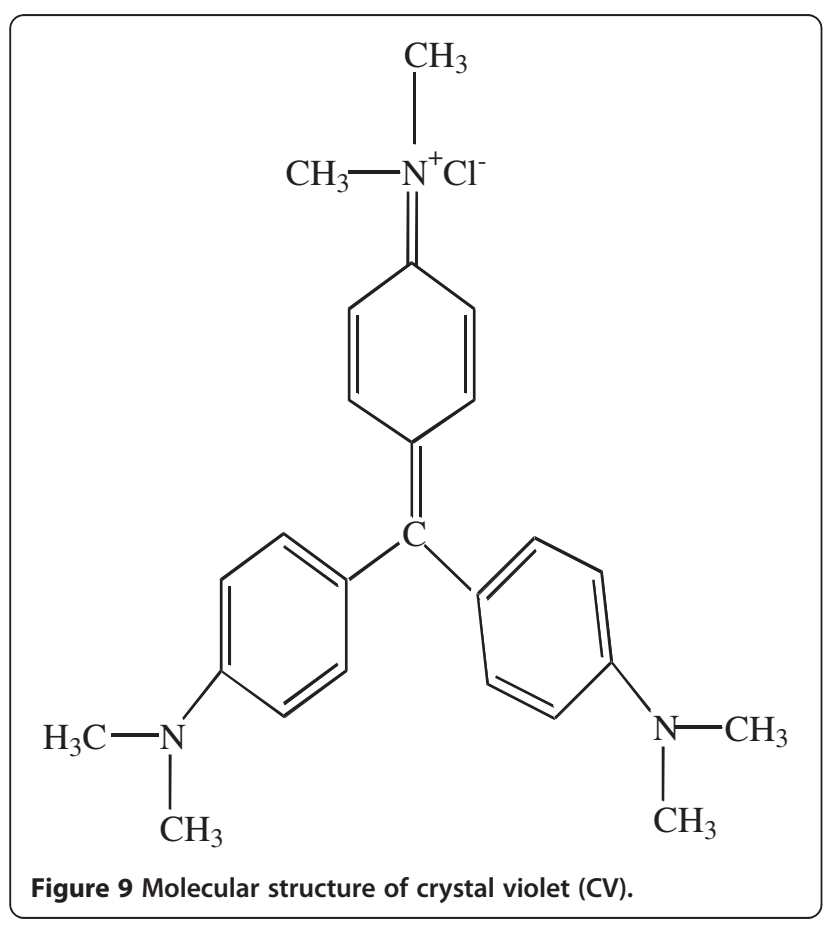

MZ-500 with a surface area of $38.4 \mathrm{~m}^{2} / \mathrm{g}$ ) was from Tayca Corporation, Japan. Zinc sulfate, ammonium carbonate, sodium hydroxide, and hydrochloric acid were purchased from BDH (Dubai, United Arab Emirates). All the chemicals were used without further purification. The $\mathrm{pH}$ of the solutions was adjusted using dilute solutions of $\mathrm{HCl}$ or $\mathrm{NaOH}$. Deionized water was used throughout the experiment.

$\mathrm{ZnO}$ was prepared through hydrothermal method. The prepared $\mathrm{ZnO}$ was characterized using a scanning electron microscope (SEM; model S-3400N, Hitachi, Tokyo, Japan), X-ray diffraction (XRD; RINT 2200, Rigaku Corporation, Tokyo, Japan) and laser-induced breakdown spectroscopy (model LAB-170, pulsed Nd: YAG, Spectra-Physics Inc., Santa Clara, CA, USA) measurement. Preparation procedure has been described in detail in our previous study [13]. Briefly, $\mathrm{ZnCO}_{3}$ was collected as a precipitate upon the addition of ammonium carbonate solution into zinc sulfate solution at $60^{\circ} \mathrm{C}$. The precipitate was filtered and washed with water to remove sulfate ions and dry it at $105^{\circ} \mathrm{C}$ in an oven. The dry $\mathrm{ZnCO}_{3}$ was further heated in a muffle furnace (OSK, Isuzu Seisa kusu Co., Ltd., Japan) at different temperatures to get desired thermally treated $\mathrm{ZnO}$ samples.

\section{Adsorption studies}

$\mathrm{ZnO}$ portions of $0.20 \mathrm{~g}$ were soaked overnight in water in stoppered bottles. The volume was made up to $40 \mathrm{~mL}$ by adding water and $\mathrm{CV}$ solution so that the desired concentration and an initial $\mathrm{pH}$, approximately $\mathrm{pH} 6$, of the dye solution were maintained. The bottles with their contents were shaken in a thermostat shaker (NTS4000AL, Tokyo Rika Kikai Co., Ltd, Tokyo, Japan) at $30^{\circ} \mathrm{C}$. Samples were withdrawn at definite intervals of time and centrifuged, and their dye concentrations were determined by measuring absorbance of the clear solution at $590 \mathrm{~nm}$ (UV-visible spectrophotometer, UV-160A, Shimadzu Corporation, Kyoto, Japan).

\section{Procedure of decolorization}

An experimental setup for photodecolorization of $\mathrm{CV}$ has been reported in our previous study [13,14]. Briefly, the visible light illumination source comprised two 40W fluorescent lamps, each with a length of $20 \mathrm{~cm}$, placed side by side. The lamp house was a wooden box with the internal surface covered with aluminum foil. The temperature inside the box was maintained at $30^{\circ} \mathrm{C}$ by regulated flow of cool air through it. The air entered the box at the bottom and flowed out at the top. The approximate intensity of the visible light at the position of the reactor was approximately $1.8 \times 10^{-4} \mathrm{~W} / \mathrm{cm}^{2}$ as 
measured using a spectroradiometer (model IL-588, International Light Technologies, Peabody, MA, USA).

Fifty-milliliter beakers, with an internal diameter of 4.0 $\mathrm{cm}$, were used as reactors. Each reactor was placed on the magnetic stirrer, and the distance of the solution surface from the lower part of the lamps was kept fixed.

$\mathrm{ZnO}$ portions of $0.20 \mathrm{~g}$ were taken in each of the several reactors containing $10 \mathrm{~mL}$ of water each. They were left overnight, and CV solutions of desired concentrations were added to the reactors in each to reach the total volume of $40.0 \mathrm{~mL}$. The contents of the reactors were agitated ultrasonically for 5 min prior to subjecting them to visible light illumination for definite times. The weight of each reactor was recorded. During the illumination, the suspensions were continuously stirred magnetically while the air passed through the lamp house. After illumination, the weights of the reactors were checked, and the weights were made up by the addition of water. Clear solutions, obtained after centrifugation, were analyzed spectrophotometrically at $590 \mathrm{~nm}$ to find out the concentration of the remaining $\mathrm{CV}$ in each reactor. The clear solutions ( 0 dye concentrations) were analyzed for free $\mathrm{Zn}^{2+}$ ions by AAS (Shimadzu, Kyoto, Japan) with reference to the standard $\mathrm{ZnSO}_{4}$ solution.

\section{Percent decolorization and mineralization}

Decolorization or color removal of $\mathrm{CV}$ was calculated as $\left(X_{\mathrm{t}} / X_{\mathrm{o}}\right) \times 100$, where $X_{\mathrm{t}}$ is the absorbance at time ' $t$ ' and $X_{\mathrm{o}}$ is that at $t=0$. On the other hand, the percent color remaining was $\left[\left(X_{\mathrm{o}}-X_{\mathrm{t}}\right) / X_{\mathrm{o}}\right] \times 100$.

In the case of mineralization/degradation, $X_{\mathrm{o}}$ is the TOC (ppm) of CV at $t=0$, and $X_{\mathrm{t}}(\mathrm{ppm})$ is its TOC at time ' $t$ '. The total organic carbon analyzer $(\mathrm{CPH} / \mathrm{CPN}$ and $638-4241 C$, Shimadzu) was used for this purpose.

\section{The initial rate of decolorization}

The equation $R_{\mathrm{i}}=k[\mathrm{CV}]_{\mathrm{i}}$ was used to determine the initial rate $\left(R_{\mathrm{i}}\right)$ by multiplying the apparent first-order rate constant $k$ with the initial concentration of $\mathrm{CV},[\mathrm{CV}]_{\mathrm{i}} \cdot k$ was determined from the slope of the plot $\ln \left([\mathrm{CV}]_{\mathrm{i}} /[\mathrm{CV}]_{\mathrm{t}}\right)$ vs time.

\section{Competing interests}

The authors declare that they have no competing interests.

\section{Authors' contributions}

MM is a PhD student and his work is the basis of the paper. AJM and TSAI are the supervisor and co-supervisor, respectively. MAH, MTS, MNI and IMII have helped with the instrumental analysis and final preparation of the paper. All the authors read and approved the final version of the manuscript.

\section{Acknowledgment}

Muhammad Muslim gratefully acknowledges the grant of study leave and deputation by the Ministry of Education, and his UGC Ph.D. Fellowship by Bangladesh University Grants Commission (UGC).

\section{Author details}

${ }^{1}$ Department of Chemistry, Faculty of Science, University of Dhaka, Dhaka 1000, Bangladesh. ${ }^{2}$ Forestry and Wood Technology Discipline, Khulna University, Khulna 9208, Bangladesh. ${ }^{3}$ The Center of Excellence in Environmental Studies, Department of Chemistry, Faculty of Science, King Abdulaziz University, Jeddah 21589, Saudi Arabia.

Received: 27 May 2013 Accepted: 11 July 2013

Published: 06 Aug 2013

\section{References}

1. Senthilkumaar, S, Porkodi, K: Heterogeneous photocatalytic decomposition of Crystal Violet in UV-illuminated sol-gel derived nanocrystalline $\mathrm{TiO}_{2}$ suspensions. J. Colloid Interface Sci. 288, 184-189 (2005)

2. Habibi, MH, Hassanzadeh, A, Mahdevi, S: The effect of operational parameters on the photocatalytic degradation of three textile azo dyes in aqueous $\mathrm{TiO}_{2}$ suspensions. J. Photochem. Photobiol. A. 172, 89-96 (2005)

3. Littlefield, NA, Blackwell, BN, Hewitt, CC, Gaylor, DW: Chronic toxicity and carcinogenicity studies of gentian violet in mice. Fundam. Appl. Toxicol. 5, 902-912 (1985)

4. Sahoo, C, Gupta, A, Pal, A: Photocatalytic degradation of Crystal Violet (C.I. Basic Violet 3) on silver ion doped $\mathrm{TiO}_{2}$. Dyes. Pigm. 66, 189-196 (2005)

5. Fox, MA, Dulay, MT: Heterogeneous photocatalysis. Chem. Rev. 93, 341-357 (2000)

6. Fujishima, A, Rao, TN, Tryk, DA: Titanium dioxide photocatalysis. J. Photochem. Photobiol. C. Photochem. Rev. 1, 1-21 (2000)

7. Gaya, Ul, Abdullah, AH: Heterogeneous photocatalytic degradation of organic contaminants over titanium dioxide: a review of fundamentals, progress and problems. J. Photochem. Photobiol. C. Photochem. Rev. 9, 1-12 (2008)

8. Chen, CC, Fan, HJ, Jang, CY, Jan, JL, Lin, HD, Lu, CS: Photooxidative N-de-methylation of crystal violet dye in aqueous nano- $\mathrm{TiO}_{2}$ dispersions under visible light irradiation. J. Photochem. Photobiol. A. Chem. 184, 147-154 (2006)

9. Chen, CC, Mai, FD, Chen, KT, Wu, CW, Lu, CS: Photocatalyzed N-de-methylation and degradation of crystal violet in titania dispersions under UV irradiation. Dyes. Pigm. 75, 434-442 (2007)

10. Ju, Y, Fang, J, Liu, X, Xu, Z, Ren, X, Sun, C, Yang, S, Ren, Q, Ding, Y, Yu, K, Wang, L, Wei, Z: Photodegradation of crystal violet in $\mathrm{TiO}_{2}$ suspensions using UV-vis irradiation from two microwave-powered electrodeless discharge lamps (EDL-2): Products, mechanism and feasibility. J. Hazard. Mater. 185, 489-1498 (2011)

11. Samira, S, Raja, A, Mohan, C, Modak, JM: Photocatalytic Degradation of Crystal Violet (C.I. Basic Violet 3) on $\mathrm{NanoTiO}_{2}$ Containing Anatase and Rutile Phases (3:1). J. Thermodynam. Cat. 3, 5 (2012)

12. The, CM, Mohamed, AR: Roles of titanium dioxide and ion-doped titanium dioxide on photocatalytic degradation of organic pollutants (phenolic compounds and dyes) in aqueous solutions: a review. J. Alloys. Compd. 509, 1648-1660 (2011)

13. Moslem, M, Habib, MA, Mahmood, AJ, Islam, TSA, Ismail, IMI: Zinc oxidemediated photocatalytic decolourization of Ponceau $S$ in aqueous suspension by visible light. Inter. Nano. Lett. 2, 30 (2012)

14. Habib, MA, Shahadat, MT, Bahadur, NM, Ismail, IMI, Mahmood, AJ: Synthesis and characterization of $\mathrm{ZnO}-\mathrm{TiO} 2$ nanocomposites and their application as photocatalysts. Inter. Nano. Lett. 3, 5 (2013)

15. Elamin, N, Elsanousi, A: Synthesis of ZnO Nanostructures and their photocatalytic activity. J. Appl. Indust. Sci. 1, 32-35 (2013)

16. Tian, C, Zhang, Q, Wu, A, Jiang, M, Liang, Z, Jiang, B, Fu, H: Cost-effective large-scale synthesis of $\mathrm{ZnO}$ photocatalyst with excellent performance for dye photodegradation. Chem. Commun. 48, 2858-2860 (2012)

17. Saquib, $\mathrm{M}$, Muneer, $\mathrm{M}: \mathrm{TiO}_{2}$-mediated photocatalytic degradation of a triphenylmethane dye (genetian violet), in aqueous suspensions. Dyes. Pigm. 56, 37-49 (2003)

18. Li, X, Liu, G, Zhao, J: Two competitive primary processes in the photodegradation of cationic triarylmethane dyes under visible irradiation in $\mathrm{TiO}_{2}$ dispersion. New J. Chem. 23, 1193-1196 (1999)

19. Lachheb, H, Puzenat, E, Houas, A, Ksibi, M, Elaloui, E, Guillard, C, Herrmann, J-M: Photocatalytic degradation of various types of dyes (Alizarins, Crocein Orange G, Methyl red, Congo red, Methylene blue) in water by UV- irradiated titania. Appl. Catal. B. Environ. 39, 75-90 (2002)

20. Hu, C, Yu, JC, Hao, Z, Wong, PK: Photocatalytic degradation of triazinecontaining azo dyes in aqueous $\mathrm{TiO}_{2}$ suspensions. Appl. Catal. B. Environ. 42, 47-55 (2003) 
21. Kang, SF, Liao, CH, Po, ST: Decolorization of textile wastewater by photo-Fenton oxidation Technology. Chemosphere 41, 1287-1294 (2000)

22. Chen, D, Roy, AK: Photodegradation kinetics of 4- nitrophenols in $\mathrm{TiO}_{2}$ suspension. Water Res. 32, 3223-3234 (1998)

23. Neppollian, B, Sankar, MV, Murugesan, V: Semiconductor assisted photodegradation of textile dye. J. Sci. Ind. Res. 6, 224-230 (2002)

24. Lagrasta, C, Bellobono, IR, Bonardi, M: Photobleaching and photomineralization of azobenzene and substituted azobenzenes in aqueous solution by photocatalytic membranes immobilizing titanium dioxide. J. Photochem. Photobiol. A. Chem. 110, 201-205 (1997)

\subsection{6/2193-8865-3-70}

Cite this article as: Habib et al:: Photocatalytic decolorization of crystal violet in aqueous nano- $\mathrm{ZnO}$ suspension under visible light irradiation. Journal Of Nanostructure in Chemistry 2013, 3:70

\section{Submit your manuscript to a SpringerOpen ${ }^{\circ}$} journal and benefit from:

- Convenient online submission

- Rigorous peer review

- Immediate publication on acceptance

- Open access: articles freely available online

- High visibility within the field

- Retaining the copyright to your article 